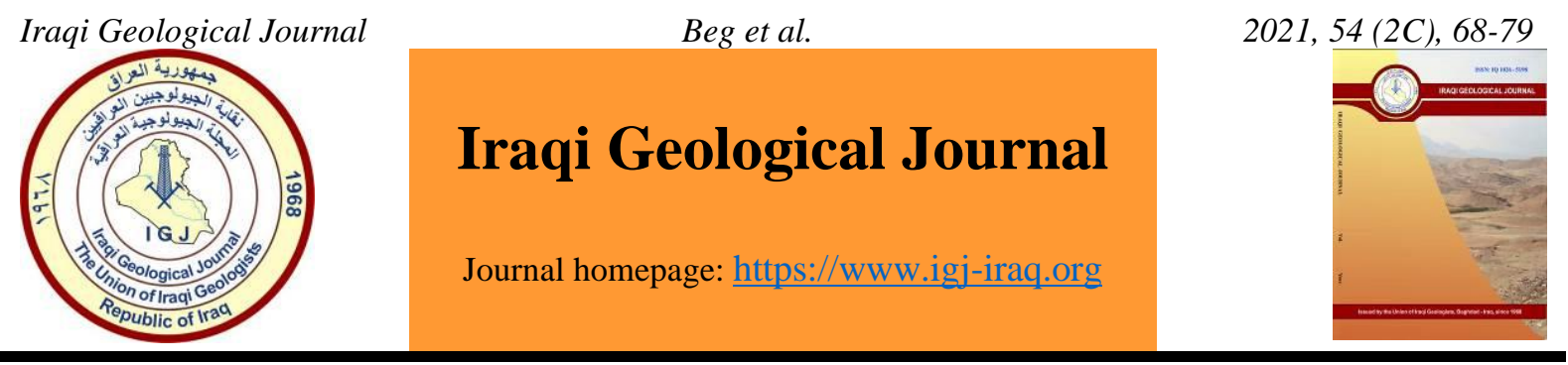

\title{
Gravel Mining Activity Impact on Riverbed Erosion and Bridge Foundation Stability
}

\author{
Ayad Ali Faris Beg, ${ }^{1, *}$, Mohammed Bahjat Thamer ${ }^{1}$, Alyaa Gatea Shiltagh ${ }^{1}$ and Ahmed H. Al- \\ Sulttani $^{2}$ \\ 1 Department of Geography, College of Education, Mustansiriyah University, Baghdad, Iraq \\ 2 Department of Environmental Planning, Faculty of Physical Planning, University of Kufa, Najaf, Iraq \\ * Correspondence: aafbeg64@uomustansiriyah.edu.iq
}

Received: 24 June 2021; Accepted: 2 August 2021; Published: 30 September 2021

\begin{abstract}
Geomorphological processes pose a risk that deserves attention, and planning to avoid that, especially in the section near to east of Tuz bridge. This section of the valley facing a dramatic increase in gravel excavation and sorting of aggregates, consequence led to a change in the pattern of river branches flow from an anabranching river to a single-channel river, which led to a concentration of river discharge during floods. On $9^{\text {th }}$ December 2018, Tuz Bridge was failed due to a heavy rainstorm three days preceding the failure event. The current study aims to conduct a field survey of all the human activities in the study area to assess river changes from remote sensing data the amount of runoff and river peak discharge based on rainfall data using SCS-CN method. This study incorporates ArcGIS, ArcGIS Earth, Google Earth, and WMS software in the data analysis. The revealed results indicate the severe modification of valley morphology and converting the river pattern to flow during flood within a single channel with flow speed exceeded the critical velocity in inducing vertical erosion of gravel and sands under the bridge's foundations and causing the displacement and settlement of the bridge. The study recommends the local administration prevent gravel mining from river valley at the upstream area of the bridge
\end{abstract}

Keywords: GIS; Remote sensing; River erosion; Geomorphic processes; Bridge stability

\section{Introduction}

The current work focuses on natural and biological geomorphic processes that modified the valley section of Ak Su River near Tuz Bridge during the last 15 years, which led to the bridge's failure. There are interacted processes, i.e., excavating aggregates with sorting of gravel and periodic floods resulting from surface runoff of river basins during rainy seasons. The failure of bridges that cross rivers or waterways occurs due to the bridge foundations' instability on the riverbed soil (Hong et al., 2012). Geomorphologic studies for a long time dealt with the effect of human activities on the nature of rivers flow, as they work together with natural factors in the development of the morphology of river channels evolution at various scales and understanding their influences are still in the infancy stage (Downs and Piégay, 2019). Topography, geomorphology, drainage, rainfall intensity and duration, evaporation and infiltration, and environmental and human processes are the main factors determining flash flood hazards (Bathrellos et al., 2016). The geomorphometric characteristics of the basin respond rapidly to

DOI: $\underline{10.46717 / i g j .54 .2 C .7 M s-2021-09-26}$ 
an extreme rainstorm. Mainly, impermeable and barren surfaces will drop down the lag time and flash flood time of concentration of surface runoff, causing high discharge in the river and putting human lives and other structures at risk (Mahmood and Rahman, 2019).

The availability of energy for the river section depends on the flow discharge and the degree of slope steepness; about $5 \%$ of the river's energy is used for erosivity and geomorphological work, while 95\% of it is consumed to overcome the forces of friction and flow resistance, and this depends on the kinetic energy of the river as a consequence of storm intensity (Charlton, 2007).The use of modern technologies that provide temporal and spatial variations led to understanding and monitoring changes in the river valley (James and Marcus, 2006; Qader et al., 2020). Estimation of surface runoff and river discharge from river watershed is another essential factor controlling river valley at the downstream area. The analysis of the rainfall-runoff relationship in any watershed is recognized as a complicated process because many factors are controlling the surface runoff in the catchment, like the intensity and duration of rainfall, soil conditions, land cover, and terrain slope (An, 2008; Anbazhagan et al., 2005; Bhadra et al., 2009; Xu et al., 2007). Surface runoff as a phenomenon occurs when the rate of precipitation exceeds the rate of water infiltration into the soil, and depend on the amount of precipitation, initial abstraction, hydrologic characteristics of the ground, and soil and antecedent moisture conditions (Lastoria and Futura, 2008; Thomas, 2015). Runoff is one of the important hydrologic variables used in the planning and managing water resources and estimation of water yield potential of a watershed (Amutha and Porchelvan, 2009; Shi et al., 2009). The use of mean areal rainfall instead of spatially distributed rainfall tends to underestimate the volumes and the peak flows when the rainfall-runoff model is calibrated by the same procedure (Arnaud et al., 2002; Tramblay et al., 2011).

The runoff estimation is the most important aspect in hydrologic modeling; the Soil Conservation Service (SCS) method developed by U.S. Department of Agriculture has utilized the rainfall and watershed coefficient (Curve Number; CN) as input for estimation of surface runoff (Nayak and Jaiswal, 2003; Sharma and Singh, 1992; USDA, 1972). SCS-CN is one of the most popular methods for computing the volume of surface runoff for ungauged watersheds (Silveira et al., 2000). The SCS-CN method has been adopted for various regions, land uses, and climatic conditions (Soulis and Valiantzas, 2012).

The $\mathrm{CN}$ value depends on land surface characteristics and hydro-soil conditions. A higher $\mathrm{CN}$ value means a higher direct surface runoff (Fan et al., 2013). The current study focused on geomorphic and hydrologic processes impacting a section of Ak Su river valley, which led to a bridge failure in Tuz district due to a heavy rainstorm on $9^{\text {th }}$ December 2018. The bridge is an essential connecting node on the main road network between northern and southern Iraqi governorates. The objective of the study is to analyze the factors that led to the failure of Tuz bridge, including biological and natural geomorphic processes and their impacts on modification happened in the valley section of $\mathrm{Ak} \mathrm{Su}$ river and to ascertain the effect of human activates on the modification of river flow pattern and to estimate the surface runoff and discharge amount due to specified rainfall according to Soil conservation Service (SCS), Curve number (CN) method.

\section{Location of the Study Area}

The current study focuses on a section of Ak Su river valley located in the downstream area of the river basin. The bridge constructed over this section was failed and collapsed on $9^{\text {th }}$ December 2018 after a heavy rainstorm in the river basin. The estimations of the surface runoff and Ak Su river basin discharge have been applied to assess their impact on bridge failure. The basin is characterized by a large variation in a physical setting, represented by many geology formations that are exposed in the basin, different soil types, and land use/land cover (Al-Sulttani and Beg, 2020). The basin extended on an area of (1859.5) square kilometers and bounded between latitudes $34^{\circ} 35^{\prime}$ to $35^{\circ} 18^{\prime} \mathrm{N}$ and longitudes 
$44^{\circ} 25^{\prime}$ to $45^{\circ} 29^{\prime}$ E Fig.1. Topographically, most of the basin is located in the mountainous area with narrow flood plains in the river valley with various landforms dispersed along the basin area resulting from rock outcrops and dominant geological structures anticline, synclines, faults, and geological formation ridges, which are given the basin complicated topography (Al-Sulttani and Beg, 2020).

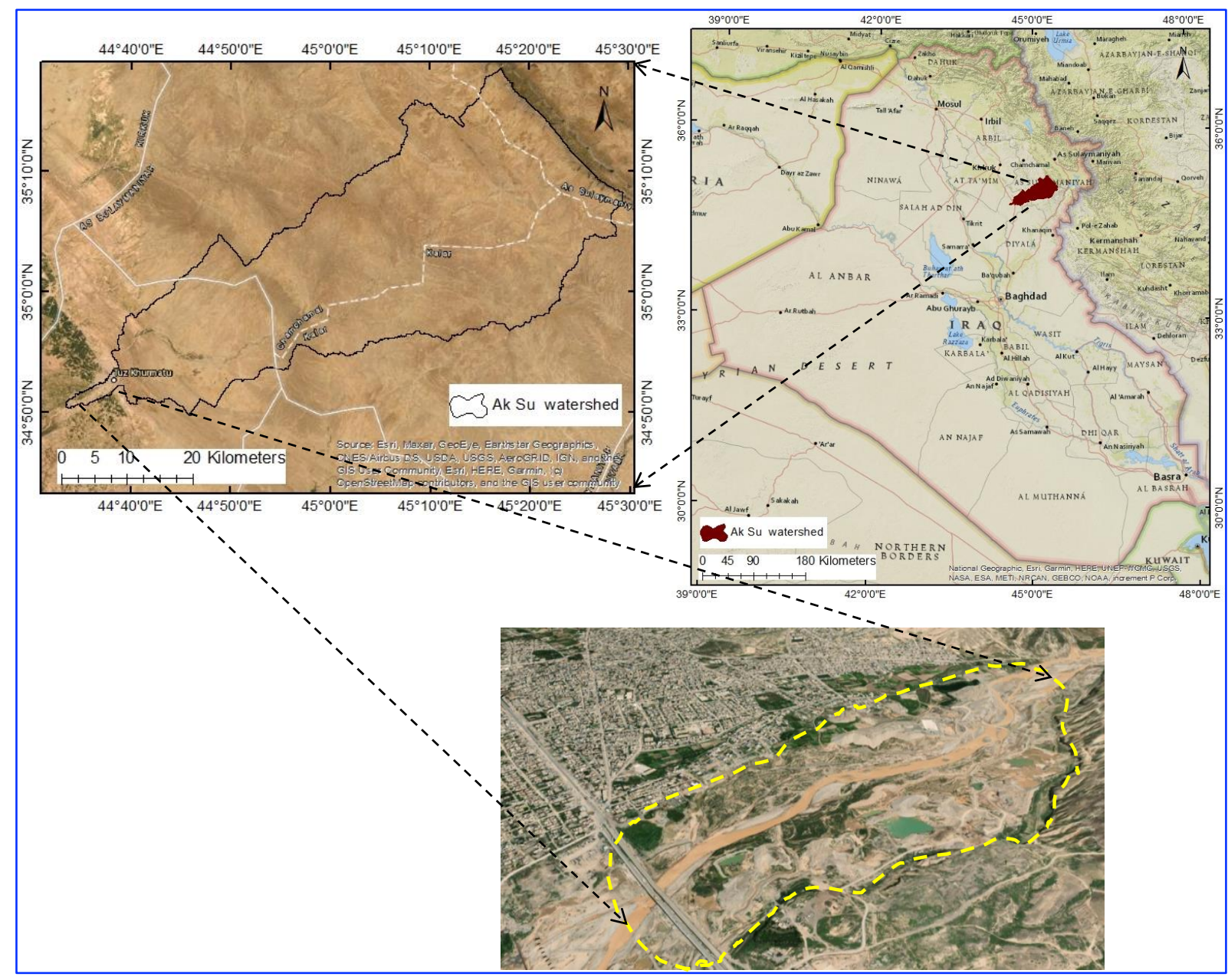

Fig.1. Location map of the study area (ESRI, base maps of licensed ArcGIS Pro. 2.8.1)

\section{Material and Methods}

Field surveying was carried out to identify the active geomorphic processes in the river valley section. The study was supported by Spatio-temporal analysis based on high-resolution satellite images. The data included for runoff computing are digital elevation model SRTM-DEM data with 1 arc-second resolution, hydrological soil group map, land use/land cover (LULC) map downloaded from Geonetwork data ${ }^{1}$, and rainfall storm data. The SRTM-DEM is downloaded Fig.2a and added to WMS software as GIS data, then converted into DEM data. Meanwhile, flow direction, flow accumulation, drainage network, basin watershed, and morphometric parameters are computed. Hydrological soil groups are prepared based on the FAO-UNESCO Digital Soil Map of the World ${ }^{2}$ Fig.2b. Soil types are classified into four soil groups, i.e., A, B, C, and D, according to their texture, infiltration, and surface runoff Fig.2c (USDA-NRCS, 2007).

\footnotetext{
${ }^{1}$ GeoNetwork - The portal to spatial data and information (fao.org), access date:21/01/2021

${ }^{2}$ http://www.fao.org/geonetwork/srv/en/metadata.show?id=14116\&currTab=distribution, access date:21/01/2021
} 
Land use land cover (LULC) Fig. 2c. LULC is classified into five classes and coded according to Anderson's codes of land use (Anderson, 1976). Rainfall storm data of 0.1 degree z 0.1 degree resolution Fig.2d are downloaded from GPM_3IMERGDL on dates 1/12 - 6/12/2018 and interpolated by ArcGIS software then converted to raster. bsq, to be opened in WMS software as a GIS data file and converted to rainfall grid.

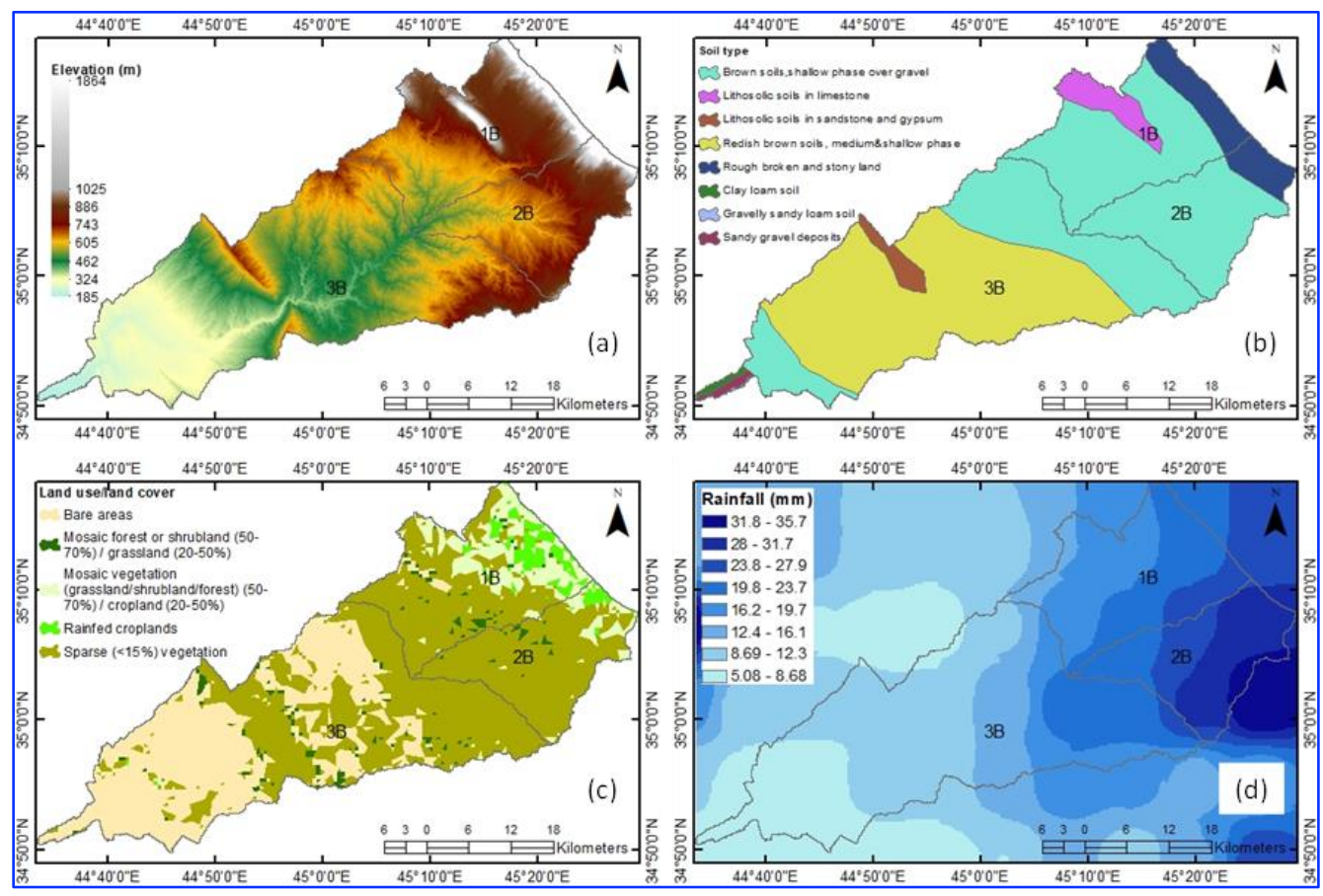

Fig.2. Input data required to execute HEC-1 model on WMS software, a). SRTM-DEM data, b). Soil types, c). LULC, and d). Rainfall storm

\subsection{Computing of Runoff}

HEC-1 model using WMS v.11 software has been used to compute surface runoff and river discharge, which is the most reliable model to compute all aspects of a watershed and hydrographs at any specific location of interest in the river basin (Araya, 2006). To execute HEC-1 model with WMS software; DEM- data, Hydrological soil groups, coded LULC according to Anderson codes (Anderson, 1976), and the rainfall storm data that caused the bridge failure are required as follows:

\subsubsection{Composite Curve Number (CCN)}

Composite Curve Number $(\mathrm{CCN})$ describes the surface potential as a function of the soil type and land use. In estimating surface runoff, the values of CN ranged between zero and 100 (USDA-NRCS, 2004). The CN zero value is a theoretical surface lower limit, which means all precipitation is infiltrated and obstructed, while 100 is the upper limit represents impermeable surfaces such as asphalt and water bodies (An, 2008). The weighted $\mathrm{CN}$ is used when the area is covered by various land use and soil groups. $\mathrm{CN}$ is calculated from the following equation (Anbazhagan et al., 2005; Sharma and Singh, 1992).

$$
C C N=\frac{\sum_{i=1}^{n} C N_{i} \times A_{i}}{A}
$$

Where $C N_{i}$ is the $\mathrm{CN}$ for $i^{\text {th }}$ area, $A_{i}$ is the $i^{\text {th }}$ area of the segment resulted from the intersection of soil type and LULC layers within the sub-basin, and $A$ is the total area of the sub-basin. The antecedent soil moisture condition AMC has a significant effect on the surface runoff. Therefore, SCS developed 
three different AMCs (AMC I, AMC II, and AMC III). Before estimating runoff for a storm event, CNs should be adjusted based on the 5-day antecedent precipitation, affecting AMC (Amutha and Porchelvan, 2009; An, 2008; Tramblay et al., 2010). The amount of rainfall along with the preceding 5 -days during Dormant and Growing season is given in Table 1.

Table 1. Amount of rainfall for AMC cases (USDA-SCS, 1972)

\begin{tabular}{ccc}
\hline AMC & \multicolumn{2}{c}{ Limits of rainfall along preceding $\mathbf{5}$ days $($ in $\mathbf{~ m m})$} \\
\hline & Dormant season & Growing season \\
I & Less than 12.7 & Less than 35.6 \\
II & $12.7-28$ & $35.6-53.3$ \\
III & Greater than 28 & Greater than 53.3 \\
\hline
\end{tabular}

The following equations are to calibrate $\mathrm{CN}$ according to the type of AMC:

$$
\begin{array}{lr}
C N_{I}=\frac{4.2 \times C N_{I I}}{10-0.058 \times C N_{I I}} & \text { for dry conditions (2) } \\
C N_{I I I}=\frac{23 \times C N_{I I}}{10+0.13 \times C N_{I I}} & \text { for wet conditions (3) } \\
C N_{I I}=C N & \text { for normal conditions (4) }
\end{array}
$$

According to the types of hydrological soil groups and LULC maps, CN values were selected for each land-use class, as per CN values given in chapter 9 (USDA-NRCS, 2004), corrected based on AMC as shown in Table 2.

Table 2. CN values based on LULC types and Hydrologic soil groups.

\begin{tabular}{cccccc}
\hline LULC- Code & Land use/Land cover type & \multicolumn{4}{c}{ Hydrologic soil group } \\
\hline \multirow{2}{*}{21} & Rainfed cropland & A & B & C & D \\
22 & Mosaic vegetation (grassland/shrubland/forest) $(50-$ & 72 & 81 & 88 & 91 \\
& $70 \%) /$ cropland (20-50\%) & 30 & 58 & 71 & 78 \\
32 & Mosaic forest or shrubland (50-70\%)/grassland (20- & 49 & 68 & 79 & 84 \\
33 & $50 \%)$ & 68 & 79 & 86 & 89 \\
77 & Sparse (<15\%) vegetation & 74 & 83 & 88 & 90 \\
\hline
\end{tabular}

\subsubsection{Execution of HEC-1 model}

HEC-1 SCS-CN Model method simulates the hydrologic process in the watershed by carrying out water balances for each element of the matrix of hydrologic soil types and LULC in the sub-areas of a watershed and then routing the resulting runoff between sub-areas. The Peak flow and time to peak values are computed as (NRCS, 2007; Sharma and Singh, 1992; USDA, 1972):

$$
\mathrm{Q}=\frac{\left(\mathrm{P}-\mathrm{I}_{\mathrm{a}}\right) 2}{\mathrm{P}-\mathrm{Ia}+\mathrm{S}} \text {. for } \mathrm{P}>\mathrm{IaQ}=\frac{\left(\mathrm{P}-\mathrm{I}_{\mathrm{a}}\right) 2}{\mathrm{P}-\mathrm{Ia}+\mathrm{S}} \text {. for } \mathrm{P}>\mathrm{Ia}
$$

Where $\mathrm{Q}$ is a direct runoff, $\mathrm{P}$ is the precipitation $(\mathrm{mm})$, I is potential maximum retention, $\mathrm{S}$ potential maximum soil retention, $\mathrm{I}$ is equal to $0.2 \mathrm{~S}$, then

$$
\mathrm{Q}=\frac{(\mathrm{P}-0.2 \mathrm{~S}) 2}{\mathrm{P}+0.8 \mathrm{~S}} Q=\frac{(P-0.2 S) 2}{P+0.8 S}
$$

Where $\mathrm{S}$ is related to $\mathrm{CN}$ value as follows:- 


$$
\mathrm{S}=\frac{25,400}{\mathrm{CN}}-254 \mathrm{~S}=\frac{25,400}{\mathrm{CN}}-254
$$

Time of concentration tc:

$$
\begin{gathered}
\mathrm{tc}=0.0195\left(\frac{\mathrm{L}^{0.77}}{\mathrm{~S}^{0.385}}\right) \mathrm{tc}=0.0195\left(\frac{L^{0.77}}{\mathrm{~S}^{0.385}}\right) \\
\left.\mathrm{T}_{\text {lag }}=0.6 \mathrm{t}_{\mathrm{c}} \text { or } \mathrm{T}_{\text {lag }}=\mathrm{L}^{0.8}\left(\frac{1000}{\mathrm{CN}}\right)-10\right)^{0.7} / 1900 \times \sqrt{\left.\mathrm{T}_{\text {lag }}=\mathrm{L}^{0.8}\left(\frac{1000}{\mathrm{CN}}\right)-10\right)^{0.7} / 1900 \times \sqrt{\mathrm{Y}} \mathrm{Y}} \mathrm{T}_{\text {lag }}= \\
\left.L^{0.8}\left(\frac{1000}{C N}\right)-10\right)^{0.7} / 1900 \times \sqrt{Y}
\end{gathered}
$$

Where $T_{\text {lag }}$ is the lag time (in hours) between the center of mass of rainfall excess and the peak of the unit hydrograph, $L$ is the watershed length in meter, $Y$ is the watershed slope in percent (Feldman, 1995). The current study used the Muskingum-type routing method, which required less data than other routing techniques such as distributed kinematic wave flow routing. Muskingum routing parameters include physical and hydraulic characteristics such as reach length, flow wave celerity, unit width discharge, and channel bed slope (Bhadra et al., 2009).

\section{Results and Discussion}

The results of field surveying, satellite data analysis, and runoff estimation are used in identifying the factors that led to the failure of the Tuz bridge as follows:

\subsection{Runoff and Flow Discharge}

The seasonal and frequent flooding during the rainy season is the prevailing characteristic of Ak Su River. Many years back, floods of the river did not leave a sensible impact on Tuz bridge foundations. However, in the last few years, gravel quarries and aggregates sorting were increased severely in the upstream side of the river valley to the east of the bridge. Hence, analysis of the runoff and flood intensity became important to identify the reality of bridge failure. The results of runoff analysis according to SCS-CN method carried out using WMS v. 11 and execution of HEC-1 Model-based on rainfall data as presented in Table 3 and results of hydrographs charts are presented in Fig. 3. Based on the results morphometric parameters and runoff estimations, most of the runoff volumes come from two sub-basins IB and 2B, in the upstream area, including about $24.1 \%$ and $40.3 \%$ of runoff volume 69.4 and 119.5 $\mathrm{m} 3 / \mathrm{sec}$ of peak runoff, respectively. A high runoff coefficient characterizes Sub-basin $2 \mathrm{~B}$ reached about 0.34 compared to other sub-basins because sub-basin $1 \mathrm{~B}$ and $2 \mathrm{~B}$ received more rainfall reached about 30.18 and 41.46 millimeters with average basin slopes of about 0.16 . However, the values of composite CNs for both sub-basins are about 79.7 and 79.5, which is less than the CN of sub-basin $3 \mathrm{~B}$.

The rainfall intensity and sub-basins topography are characterized by relatively steep slopes, which are the main factors that cause high runoff from the upstream area of $\mathrm{Ak} \mathrm{Su}$ basin. To illustrate the variations in runoff parameters, including runoff volume, peak runoff, and time to reach peak runoff, flowchart and hydrographs details are presented in Fig. 3. The runoff parameters are varied during a surface runoff on sub-basins and flow into sub-basins outlets and their flow into main routes till reaching the main basin outlet (7c) as shown in Fig. 4. The hydrograph shows the peak runoff (discharge) of about $223 \mathrm{~m} 3 / \mathrm{sec}$. The time required to reach the peak runoff to the interesting section of $\mathrm{Ak} \mathrm{Su}$ river valley will take about 340 minutes. This discharge was passed under the Tuz bridge through a single channel and flow with high speed that induced vertical erosion under the bridge foundations and led to the bridge's failure. 
Table 3. Rainfall-runoff data for the storm event at $9^{\text {th }}$ December 2018

\begin{tabular}{|c|c|c|c|c|c|c|c|}
\hline Basin name & 3B & 1B & $2 \mathrm{~B}$ & Basin name & 3B & 1B & $2 B$ \\
\hline Basin area $(\mathrm{Km} 2)$ & 1100.09 & 444.88 & 314.57 & Time to peak (min) & 550 & 320 & 310 \\
\hline sub-basin slope & 0.12 & 0.16 & 0.16 & Peak runoff (m3/sec) & 58.71 & 69.4 & 119.57 \\
\hline sub-basin length $(\mathrm{km})$ & 74.4 & 31.4 & 32.9 & Volume of runoff (m3) & 2396778 & 1610955 & 2703113 \\
\hline Sub-basin lag time (tl) & 8.71 & 4.73 & 4.6 & $\%$ Volume of runoff & 35.72 & 24.01 & 40.3 \\
\hline $\begin{array}{l}\text { Sub-basin time of } \\
\text { concentration (tc) }\end{array}$ & 14.52 & 7.88 & 7.67 & Average runoff (m3) & 1943.1 & 1306 & 2191.4 \\
\hline $\begin{array}{l}\text { Composite Curve Number } \\
(\mathrm{CCN})\end{array}$ & 86.17 & 79.69 & 79.53 & Rate of runoff $(\mathrm{m} 3 / \mathrm{sec})$ & 4.6 & 7.6 & 18 \\
\hline rainfall $(\mathrm{mm})$ & 18.95 & 30.18 & 41.46 & $\begin{array}{l}\text { Calculated Runoff } \\
\text { coefficient }\end{array}$ & 0.09 & 0.14 & 0.34 \\
\hline
\end{tabular}

\subsection{Assessment of Flow Velocity}

The flow velocity of the river in the study area was estimated according to Manning equation, discharge equation, and peak flow time with the length of the main channel of the river:

According to Manning equation:

$$
\begin{aligned}
& v=\frac{R^{0.67} \times S^{0.5}}{n} \\
& R=A / p_{w}
\end{aligned}
$$

Where $\mathrm{R}$ is the hydraulic radius, $\mathrm{S}$ is channel slope, $\mathrm{n}$ is manning roughness coefficient (about 0.04 for mainly gravels and cobbles with few boulders), A cross-sectional area (m2), and $\mathrm{Pw}$ is wetted perimeter $(\mathrm{m})$. Based on measurement carried out during field survey and from 3D section computed from ArcGIS Earth; the measured cross-section area is about 45 square meters, and the wetted perimeter measured from the trace of flood in the river channel is equal to 30 meters.

$\mathrm{R}=45 \mathrm{~m} 2 / 30 \mathrm{~m}=1.5$

$$
v=\frac{1.5^{0.67} \times 0.02^{0.5}}{0.04}=4.64 \mathrm{~m} / \mathrm{sec} .
$$

Based on river cross-section and discharge value

According to the peak discharge $\left(Q_{p}\right)$ of the basin outlet and river cross-section area, flow velocity was calculated as follow:

$$
\mathrm{Q}=\mathrm{V} \cdot \mathrm{A}
$$

$\mathrm{V}=\mathrm{Q} / \mathrm{A}=223.65 \mathrm{~m}^{3} / \mathrm{sec} . / 45 \mathrm{~m}^{2}=4.97 \mathrm{~m} / \mathrm{sec}$.

Based on main channel length and time to peak flow on basin outlet.

The main channel length measured from DEM using ArcGIS network and route selection tool is about 97456 meters, and time to peak flow is 340 minutes, then

$$
\mathrm{V}=\text { Main channel length / Time to peak }
$$

$\mathrm{V}=97456 / 340 * 60=4.8 \mathrm{~m} / \mathrm{sec}$.

To prove whether the river flow energy is enough to start vertical riverbed erosion in the deposits, mainly of gravel and sand deposits. Haustrum (1935) diagram was implemented Fig. 5, which shows the mean flow velocity at which particles of a given size are entrained, transported, and deposited (Charlton, 2007; Hjulstrom, 1935). According to the Hjulstrøm diagram and measured flow, velocity indicates the velocity overcomes the critical velocity. When water strikes the bridge columns, the flow becomes very turbulent under bridge pillars, leading to displacement and settlement of the bridge foundation.

\subsection{Impact of Human Activates}

To achieve a conceptual understanding of spatial and temporal variations in the morphology of river channel and river valley; field measurements of $\mathrm{Ak} \mathrm{Su}$ river valley section were conducted, 
including measurement of river cross-section, river wetted perimeter near to the Tuz bridge, channel, location of gravel quarries, and aggregate sorting hills, to assess their impact on modification of river flow pattern in the study area Plate 2 . Field survey shows the human activities are mainly controlled and captured the river flow and concentrated in a single narrow channel passing under the bridge. The resent deposits in the river valley mainly consist of gravel and sandy gravel which are characterized as loose sediments. The pillars under the bridge foundations, unfortunately, are shallow in-depth, about 3 meters. Therefore, the river's floods led to removing the sands and clay sediments, which increased erodibility of gravels from the surrounding area of the bridge pillars and below them consequently. The bridge foundation is displaced and led to bridge settlement as shown in Plate 2a, vertical erosion in the riverbed reached about 2 meters below the normal level of the channel bed.

Two images of different dates are used for showing the occurred variations and monitor and identify the morphological modification of the Ak Su river using remote sensing data. As appear in the image taken from Google Earth collected in 2002, as shown in Fig.6a, the river flow is the anabranching pattern and laterally active channels. The river passes below the bridge through multiple channels. Besides, there were no active gravel quarries in the valley section before 2003. In comparison, Fig.6b shows the image provided by Maxar on 24th April 2019 with a spatial resolution of $0.31 \mathrm{~m}$ collected from ArcGIS Earth with 3D data. From the analysis 3D view of image and cross-sections Fig.6c and Fig.7 indicate the river has been subjected to a severe modification by blocking all the branches of the river by pits and hills due to excavations of gravels and sands and aggregate sorting, consequently led to the capturing the river in one narrow channel, which increased the river's energy to downcutting of channel bed by vertical erosion, because the river flow in alluvial deposits consists mainly of gravel and sand.

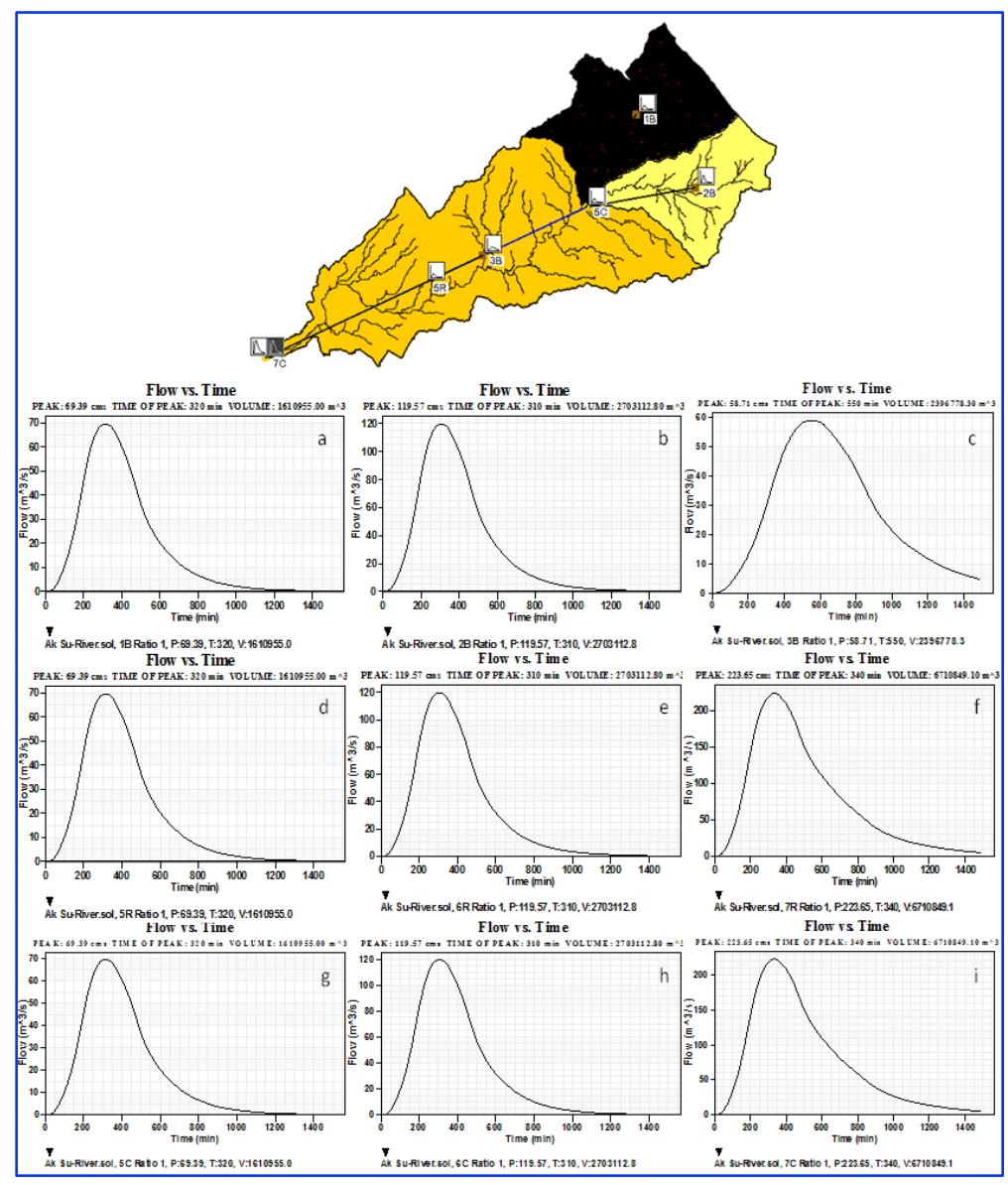

Fig.3. Hydrographs of Ak Su river sub-basins consequence of accumulative storms during $7^{\text {th }}$ to $9^{\text {th }}$ December 2018, a-c). Sub-basins hydrographs, d-f). Route hydrographs, and g-i). Outlet hydrographs 


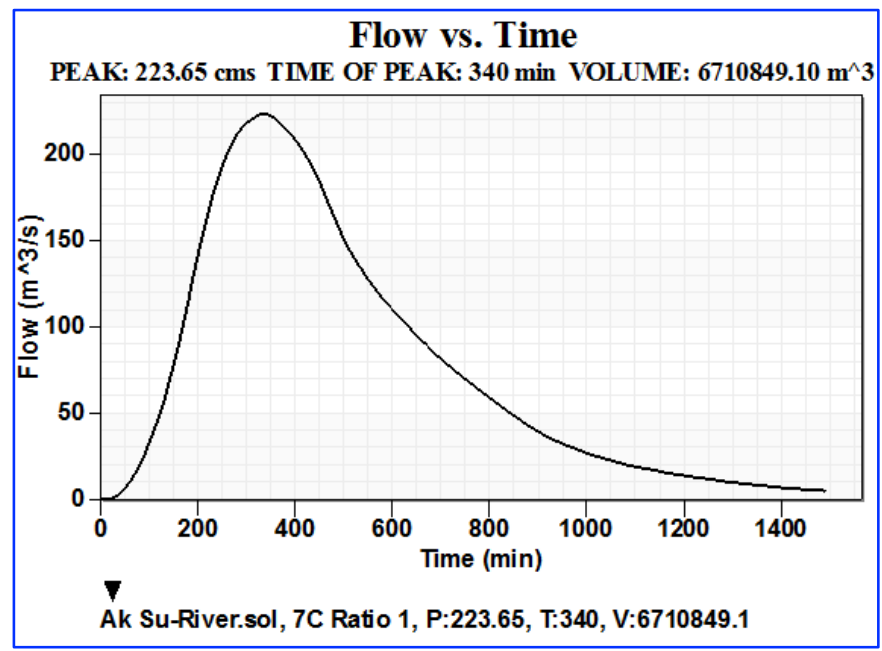

Fig.4. Hydrograph of the outlet of Ak Su basin

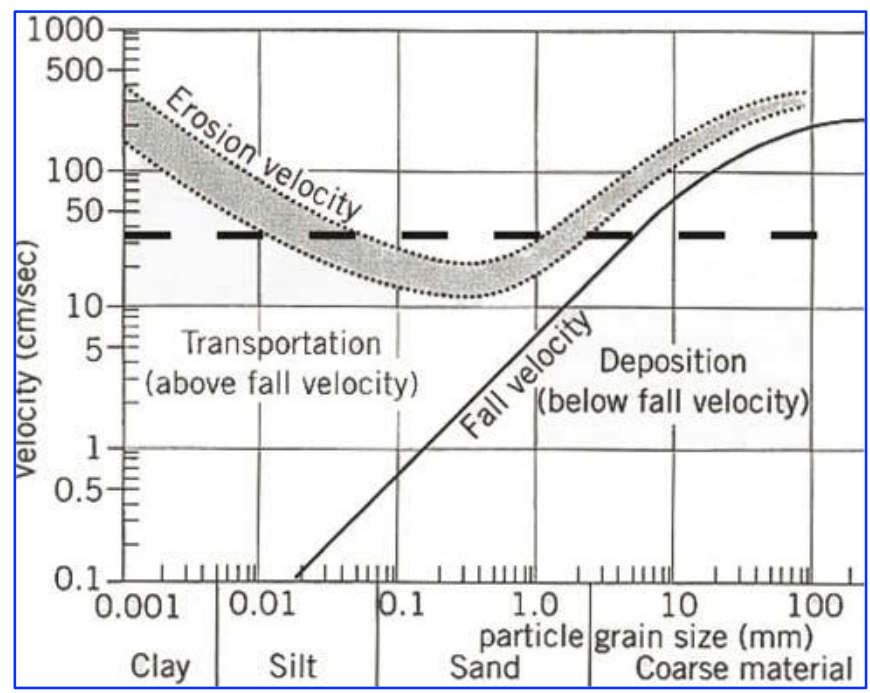

Fig.5. Hjulstrøm diagram shows the water velocity which caused erosion or deposition of sorted sediment (Hjulstrom, 1935)

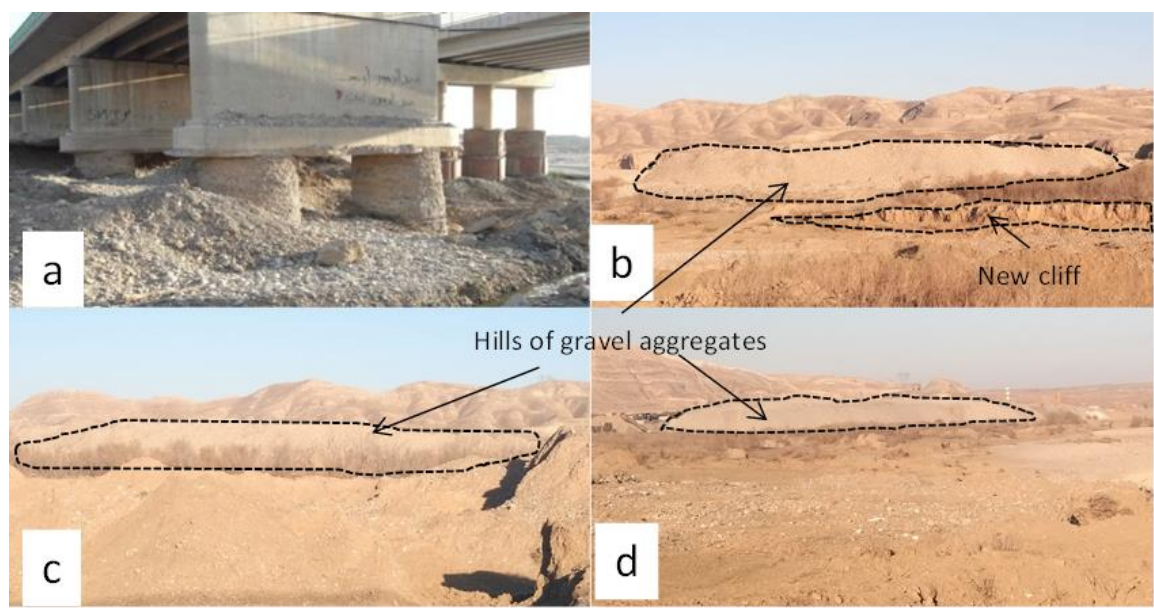

Plate 2. a). Shows flood impact on Bridge foundations, b,c, and d). Gravel hills accumulated in the river valley (Field survey on 25 September 2020). 


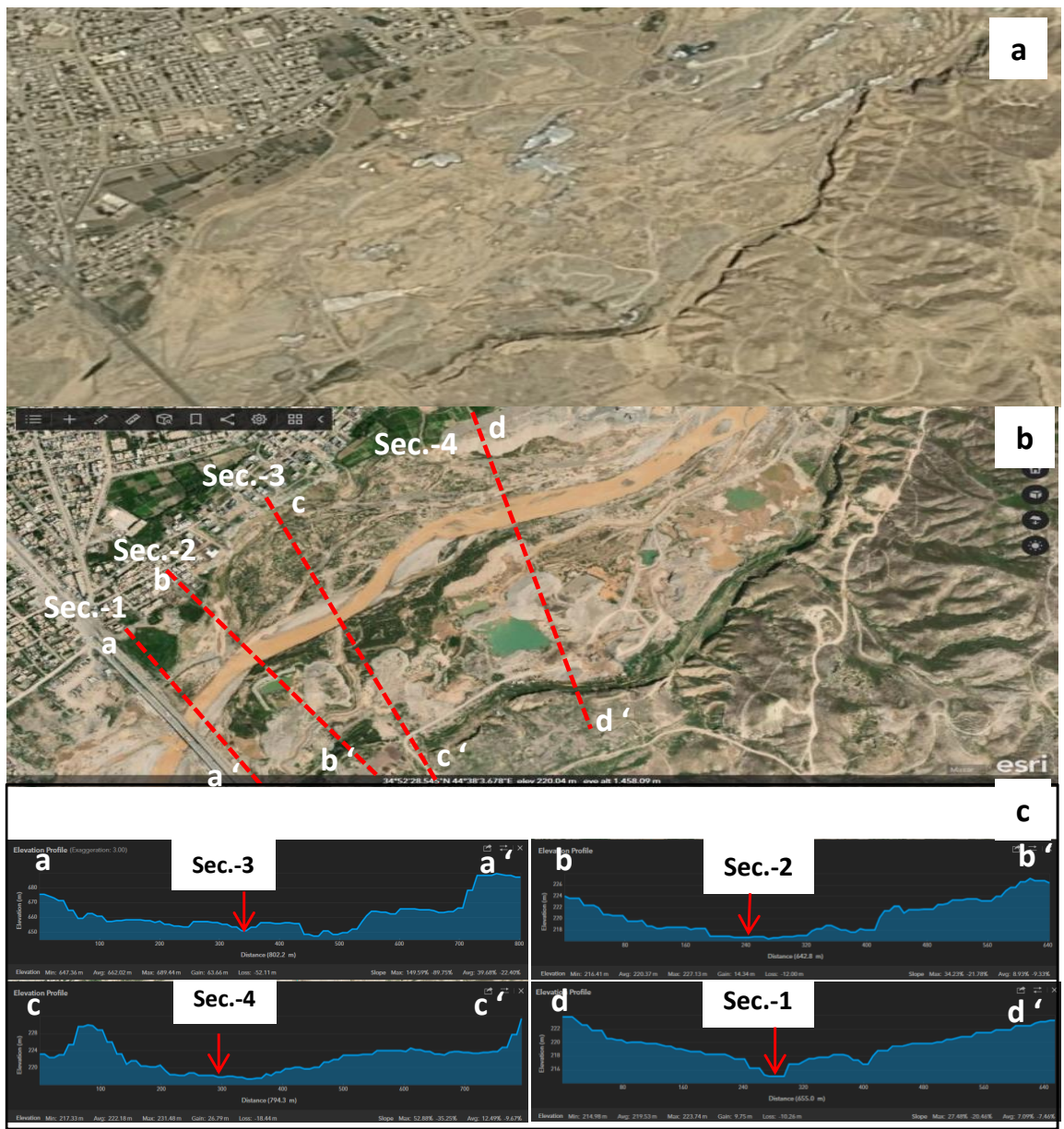

Fig. 6 a). Google earth image shows an anabranching river pattern, b). Location of river valley sections c). Cross-sections of Ak Su river valley using ArcGIS earth software (Esri, Maxar, GeoEye, Earthstar Geographics, CNES/Airbus DS, USDA, USGS, AeroGRID, IGN, and the GIS User Community, image date $24 / 4 / 2019$ )

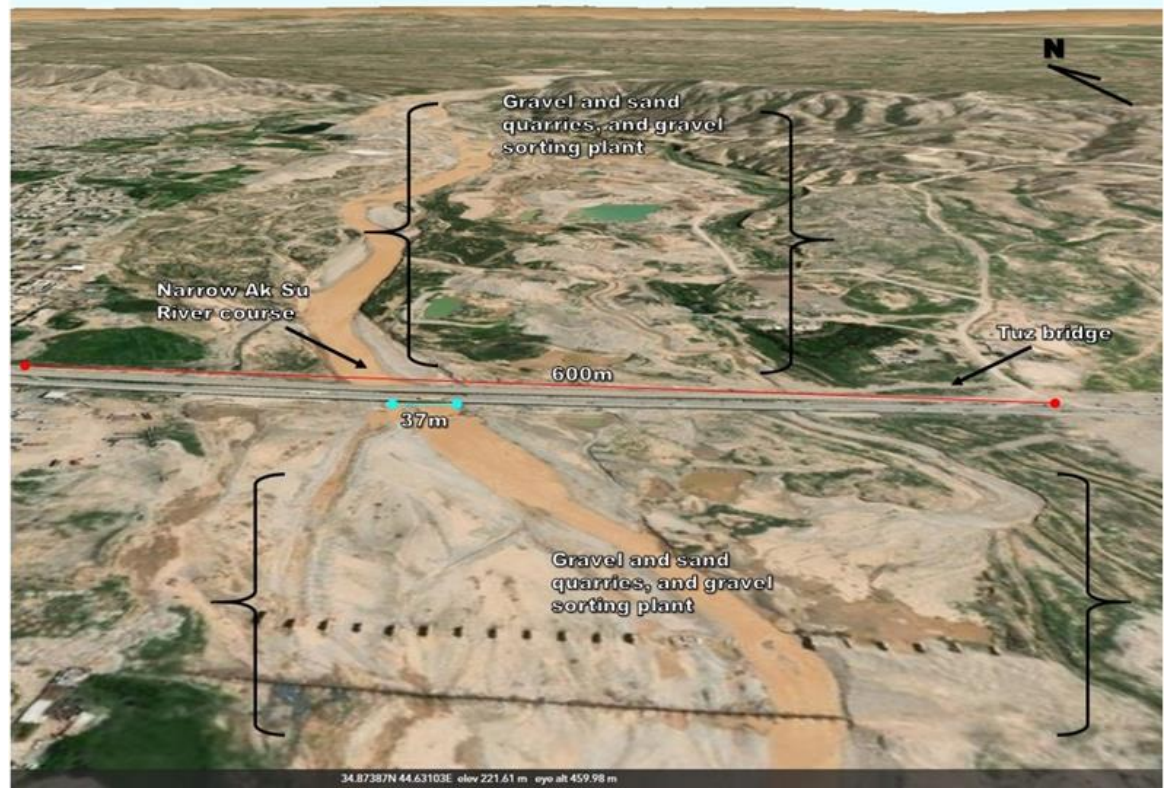

Fig. 7. Ak Su river channel surrounded by gravel aggregates hills and pits using ArcGIS earth software (Esri, Maxar, GeoEye, Earthstar Geographics, CNES/Airbus DS, USDA, USGS, AeroGRID, IGN, and the GIS User Community, image date 24/4/ 2019) 


\section{Conclusions}

Satellite image analysis showed that the river flow pattern was changed due to human activities from anabranching river flow pattern to single-channel river and consequently increased erosivity power of the river flow's erosion power during floods. The Surface runoff has reached about $223 \mathrm{~m}^{3} / \mathrm{sec}$ on $9^{\text {th }}$ December 2018. The days preceding that led to increasing the river erosivity, with a flow velocity that exceeded the critical speed required for the erosion of the gravel and sand from the river bed, even though the flood events of the river had occurred with the same intensity or more in previous years. However, the foundations of the bridge were not affected because the river was crossing the bottom of the bridge through multiple channels, which will reduce erosivity power of the river branch, but the human activities in the river valley and the accumulation of gravel hills as a waste of gravels quarries and aggregates sorting, which are severely constructed after 2003. It made the river flow in a confined single narrow channel, which led to increasing the river's flow rate and consequently increased its discharge, velocity, and vertical erosivity power and reached the bottom of the bridge pillars, leading to bridge failure.

\section{Acknowledgements}

The authors are honored to record acknowledges to the University of Mustansiriyah to support the arrangement of the field survey and their follow-up the steps research completing. We are pleased to record our thanks to the University of Kufa for their collaboration in this work. Our grateful as well to the Editor in Chief Prof. Dr. Salih M. Awadh, the Secretary of Journal Mr. Samir R. Hijab, and the Technical Editors for their great efforts and valuable comments.

\section{References}

Al-Sulttani, A. H., Beg, A. A., 2020. Hypsometric analysis of Al-Adhaim Basin using a new GIS-technique. Iraqi Geological Journal, 53(2), 154-170.

Amutha, R., Porchelvan, P., 2009. Estimation of surface runoff in Malattar sub-watershed using SCS-CN method. Journal of the Indian Society of Remote Sensing, 37(2), 291-304.

An, W., 2008. The Study of GIS-Based Hydrological Model in Highway Environmental Assessment, VDM Verlag, Dr. Müller, 204 pp.

Anbazhagan, S., Ramasamy, S., Gupta, S.D., 2005. Remote sensing and GIS for artificial recharge study, runoff estimation and planning in Ayyar basin, Tamil Nadu, India. Environmental Geology, 48(2), 158-170.

Anderson, J. R., 1976. A land use and land cover classification system for use with remote sensor data, 964. US Government Printing Office, 964, 34.

Araya, B.M., 2006. Busseron Creek Watershed Detention Pond and Peak Runoff Analysis Using HEC-1.

Arnaud, P., Bouvier, C., Cisneros, L., Dominguez, R., 2002. Influence of rainfall spatial variability on flood prediction. Journal of Hydrology, 260(1-4), 216-230.

Bathrellos, G., Karymbalis, E., Skilodimou, H., Gaki-Papanastassiou, K., Baltas, E., 2016. Urban flood hazard assessment in the basin of Athens Metropolitan city, Greece. Environmental Earth Sciences, 75(4), 319.

Bhadra, A., Bandyopadhyay, A., Singh, R., Raghuwanshi, N.S., 2009. Rainfall-runoff modeling: Comparison of two approaches with different data requirements. Water Resources Management, 24(1), 37-62.

Charlton, R., 2007. Fundamentals of fluvial geomorphology. 1st Ed., Routledge, USA, 234 pp.

Downs, P.W. and Piégay, H., 2019. Catchment-scale cumulative impact of human activities on river channels in the late Anthropocene: implications, limitations, prospect. Geomorphology, 338, 88-104.

Fan, F., Deng, Y., Hu, X., Weng, Q., 2013. Estimating composite curve number using an improved SCS-CN method with remotely sensed variables in Guangzhou, China. Remote Sensing, 5(3), 1425-1438.

Feldman , A.D. 1995. HEC - 1 flood hydrograph package. In V.P. Singh (Ed.) computer models of watershed hydrology, Water Resources Publications, 119, 150.

Hjulstrom, F., 1935. Studies of the morphological activity of rivers as illustrated by the river fyris, Bulletin. Geological Institute Upsalsa, 25, 221-527. 
Hong, J.H., Chiew, Y.M., Lu, J.Y., Lai, J.S., Lin, Y.B., 2012. Houfeng bridge failure in Taiwan. Journal of Hydraulic Engineering, 138(2), 186-198.

James, L.A., Marcus, W.A., 2006. The human role in changing fluvial systems: Retrospect, inventory and prospect. Geomorphology, 79(3-4), 152-171.

Lastoria, B., Futura, G., 2008. Hydrological processes on the land surface: A survey of modelling approaches. FORALPS Technical Report, 9. University of Trento, Italy, Trento, Italy, 56 pp.

Mahmood, S., Rahman, A.-u., 2019. Flash flood susceptibility modeling using geo-morphometric and hydrological approaches in Panjkora Basin, Eastern Hindu Kush, Pakistan. Environmental earth sciences, 78(1), 1-16.

Nayak, T., Jaiswal, R., 2003. Rainfall-runoff modelling using satellite data and GIS for Bebas river in Madhya Pradesh. Journal of the Institution of Engineers. India. Civil Engineering Division, 84, 47-50.

NRCS, U., 2007. Estimation of direct runoff from storm rainfall. In 'National engineering handbook'.(Eds V Mockus, AT Hjelmfelt, HF Moody). US Department of Agriculture, Natural Resources Conservation Service: Washington, DC, 1-79.

Qader, R.M., 2020. Engineering geological assessment of the rock slope stability along the proposed lerabire road in the Mergasur city, kurdistan, Iraq. The Iraqi Geological Journal, 53 (2F) 65-82.

Sharma, K.D., Singh, S., 1992. Runoff estimation using Landsat Thematic Mapper data and the SCS model. Hydrological Sciences Journal, 37(1), 39-52.

Shi, Z.H., Chen, L.D., Fang, N.F., Qin, D.F. and Cai, C.F., 2009. Research on the SCS-CN initial abstraction ratio using rainfall-runoff event analysis in the Three Gorges Area, China. Catena, 77(1), 1-7.

Silveira, L., Charbonnier, F., Genta, J., 2000. The antecedent soil moisture condition of the curve number procedure. Hydrological Sciences Journal, 45(1), 3-12.

Soulis, K.X., Valiantzas, J.D., 2012. Identification of the SCS-CN parameter spatial distribution using rainfallrunoff data in heterogeneous watersheds. Water Resources Management, 27(6), 1737-1749.

Thomas, A., 2015. Modelling of spatially distributed surface runoff and infiltration in the Olifants River catchment, water management area using GIS. International Journal of Advanced Remote Sensing and GIS, 4(1), 828862.

Tramblay, Y., Bouvier, C., Ayral, P.A., Marchandise, A., 2011. Impact of rainfall spatial distribution on rainfallrunoff modelling efficiency and initial soil moisture conditions estimation. Natural Hazards and Earth System Science, 11(1), 157-170.

Tramblay, Y., Bouvier, C., Martin, C., Didon-Lescot, J.-F., Todorovik, D., Domergue, J.-M., 2010. Assessment of initial soil moisture conditions for event-based rainfall-runoff modelling. Journal of Hydrology, 387(34), 176-187.

USDA-NRCS, 2004. Part 630 Hydrology,National Engineering Handbook. Hydrologic Soil-Cover Complexes, Washington, D.C.

USDA-NRCS, 2007. Part 630 Hydrology: National Engineering Handbook: Hydrologic Soil Groups, USDA, Washington, D.C.

USDA-SCS, 1972. National Engineering Handbook: Hydrology. Washington, DC.

Xu, L., Zhang, Q., Li, H., Viney, N.R., Xu, J., Liu, J., 2007. Modeling of surface runoff in Xitiaoxi catchment, China. Water Resources Management, 21(8), 1313-1323. 